\title{
AÇÃO COLETIVA E MEDIÇÃO RELIGIOSA NO CAMPO NO BRASIL: EVIDÊNCIAS HISTÓRICAS NA ARQUIDIOCESE DE MARIANA - MINAS GERAIS
}

\author{
B. C. FONSECA* e A. L. C. FIÚZA \\ Universidade Federal de Viçosa \\ bruno_fonsecacosta@hotmail.com
}

Artigo submetido em janeiro/2015 e aceito em junho/2015

DOI: 10.15628/holos.2015.2694

\section{RESUMO}

Este trabalho pretende alinhar os movimentos de Ação Coletiva intermediado pela Igreja Católica Progressista no Brasil às grandes teorias sobre movimentos sociais, especificamente no que tange aos processos de resistências de comunidades rurais da Zona da Mata Mineira. A teoria sobre movimentos sociais abordadas evidenciou uma mudança de concepções marxistas/funcionalista, passando por três outras teorias até chegar a reelaborações teóricas mais atuais, a saber: Teoria da Mobilização de Recursos que explicita a dimensão micro organizacional, sendo extremamente racional; Teoria do Processo Político, que retratou em sua análise explicativa o ambiente macropolítico; e a Teoria dos Novos Movimentos Sociais que privilegiou os aspectos simbólicos e cognitivos. Utilizamos como
\end{abstract}

procedimentos metodológicos a análise documental e bibliográfica. Os resultados analisados que explicam a emersão de movimentos eclesiais progressistas na Arquidiocese incidiram em dois tipos de Estruturas de Oportunidades Políticas: I) a nomeação de um bispo simpatizante com os ideais da Teologia da Libertação e II) o aparecimento dos conflitos socioambientais. Destarte, os tipos de estratégias utilizadas pelos movimentos sociais puderam ser classificadas em três tipos, nomeadas neste manuscrito como técnicocientífico, enfrentamento direto e educaçãoinformação. A Igreja Católica contribuiu, portanto, adicionando elementos místicos a essas estratégias historicamente utilizadas.

PALAVRAS-CHAVE: Ação Coletiva, Igreja Católica, Movimentos Sociais.

\section{CLASS ACTION AND RELIGIOUS MEASUREMENT ON FIELD IN BRAZIL: HISTORICAL EVIDENCE IN ARQUIDIOCESE MARIANA - MINAS GERAIS}

\begin{abstract}
This work aims to align the movements of Collective Action brokered by the Catholic Church in Brazil Progressive with the major theories of social movements, specifically with respect to the processes of rural communities in resistance of the Zona da Mata Mineira. The theory of social movements addressed showed a change of Marxist / functionalist conceptions, through three other theories to get the most current theoretical reworkings, namely: Resource Mobilization Theory that explains the organizational micro dimension being extremely rational; Political Process Theory, who portrayed in his explanatory analysis the macro-political environment; and the Theory of New Social Movements
\end{abstract}

that favored the symbolic and cognitive aspects. Used as instruments to document and literature review. The results analyzed that explain the emergence of progressive ecclesial movements in the Archdiocese focused on two types of structures Opportunities Policies: I) the appointment of a bishop sympathetic to the ideals of liberation theology and II) appearance of environmental conflicts. Thus, the types of strategies used by social movements could be classified into three types, this manuscript titled as technical-scientific, direct engagement and education-information. The Catholic Church contributed thus adding mystical elements to these strategies historically used.

KEYWORDS: Collective Action, Catholic Church, Social Movements. 


\section{INTRODUÇÃO}

O ano de 2014 foi de muita esperança para os movimentos sociais, sobretudo para os ligados aos movimentos progressistas da Igreja Católica. A saída do Papa Bento XVI, considerado um papa extremamente conservador, e a entrada de um papa Latino Americano acendeu a chama da luta popular em diversas partes do mundo. Para muitos, o olhar diferenciado do novo Papa - Jorge Mario Bergoglio "Francisco" - para as desigualdades sociais no mundo se confirmou com o encontro, em Roma, com 200 representantes de organizações sociais de todo o mundo, do dia 27 a 29 de outubro. Na ocasião o Papa encorajou as lutas sociais de movimentos populares, enfatizando a necessidade de que toda a população tenha acesso a "terra, moradia decente e trabalho digno". Francisco enfatizou, outrossim, que a Reforma Agrária é necessária, sendo uma obrigação moral, indispensável para erradicar vítimas da fome e da desigualdade provocada pela concentração de terras, espelho do capitalismo no campo.

O teólogo Leonardo Boff, um dos estudiosos mais polêmicos e de repercussão mundial sobre a Igreja Católica Progressista, retratou em seu blog pessoal ${ }^{1}$ que o Encontro Mundial dos Movimentos Populares foi um evento inédito em mais de 2.000 anos de Igreja, organizado pelo próprio Vaticano em conjunto com movimentos populares. Boff ressalta que o Papa não chamou cientistas sociais ou políticos para discutir os processos de resistências populares no mundo a partir de uma visão academicista, convidou, entretanto, os próprios atores envolvidos nos movimentos. Atraiu atenção as duras críticas que o Papa fez ao Capitalismo "desumano" chamando-o inclusive de "diabo", assim como exortou a atuação dos bancos e das transnacionais que tem causado a exclusão social de populações destituídas de terra para plantar, de trabalho e de moradia.

Em verdade, o protagonismo do grande clero da Igreja Católica incentivando movimentos sociais no campo não é algo comum de se ver ao longo da história, sendo este, via de regra, um papel realizado pelos movimentos eclesiais de base, mormente. As organizações dos movimentos eclesiais de base, sobretudo com atuação no meio rural, surgiram na América Latina por volta dos anos 50 e 60. A América Latina passava por um intenso processo de industrialização, culminando em graves desigualdades sociais, êxodo rural e uma massa de proletariados marginalizados nos grandes centros urbanos. Não obstante, com a Revolução Cubana de 59, emergiu diversas lutas sociais, movimentos armados, sucessão de golpes militares e a crise do sistema político vigente (LÖWY, 1989). Nesse contexto também surgiu os princípios da Teologia da Libertação que foi um importante instrumento para reunião de milhares de pessoas em organizações sociais (LEVY, 2009), orientando a Igreja Católica para ações políticas que minimizassem a exclusão social, reflexo de uma Igreja Libertadora, que tinha como foco a opção preferencial pelos pobres.

É importante destacar, outrossim, o Concílio Vaticano II, em 1962, que abriu portas para a emergência dos ideais da Teologia da Libertação. Segundo Levy (2009), após o Vaticano II, o olhar da Igreja para as desigualdades sociais que afligiam o mundo permitiu a emergência da Teologia da Libertação comprometida com o fortalecimento da sociedade civil ao final da Ditadura Militar

\footnotetext{
${ }^{1}$ Para ver o artigo completo acesse: <http://leonardoboff.wordpress.com/2014/11/04/o-papa-francisco-junto-comos-movimentos-sociais-populares-critica-o-capitalismo-joao-pedro-stedile/>.
} 
e durante a década de 80 , possibilitando a reunião de milhares de pessoas em organizações sociais, sobretudo no meio rural, com a criação de sindicatos, associações, cooperativas, grupos de ação política, entre outros. No Brasil, a manifestação mais visível da Teologia da Libertação está na criação das Comunidades Eclesiais de Base (CBEs). A Igreja Católica, nesse período, mobilizou um grande projeto de formação de lideranças, visando a propagação de uma comunidade mais justa e fraterna. Idealizados através das CEBs, os projetos buscavam formar lideranças conscientes, sensíveis para perceber os conflitos sociais, identificar os opressores do povo e construir o reino de Deus (KLEIN, 2009).

Desde então foi possível perceber diversos movimentos de resistências no Brasil a citar: Encruzilhada do Natalino - Luta pela terra no município de Ronda Alta, Rio Grande do Sul. Foi o primeiro processo de resistência após o Regime Militar de 64; Afogados - Por ocasião da construção de uma barragem em 1970 entre os municípios de Cruz Alta e Santa Maria, no Rio Grande do Sul, mais de trezentas famílias foram expulsas de suas terras; Campo Erê - No município de Santa Catarina, Rio Grande do Sul, famílias resistiram acampadas no antigo latifúndio, Fazenda Burro Branco, de 1980 a 1982; Marmeleiro - O município de Marmeleiro, no Paraná, foi um importante palco de lutas pela terra desde 1940 devido ao intenso processo de grilagem na região; Lutas em São Paulo - Desde 1967 diversas lutas pela terra ocorrem no estado de São Paulo colocando em pauta os processos de grilagem na região; $A$ luta dos posseiros no Araguaia - Na divisa entre o Pará, Goiás e Mato Grosso posseiros resistem a implantação de diversas projetos por parte de grandes empreendedores; $A$ luta dos povos da floresta - No norte do País Índios sofreram com os impactos de projetos estatais e privados; Seringueiros no Acre Em 1970, liderados por Chico Mendes, seringueiros se organizaram contra grandes fazendeiros pelo direito de reprodução socioeconômica em suas terras; (IOKOI, 1996).

Não obstante, trazemos para este estudo em específico, as mobilizações da Igreja Católica em conjunto com outros movimentos sociais na Zona da Mata Mineira, Minas Gerais, Brasil. Impulsionado pela grande demanda de energia e pelos pressupostos desenvolvimentistas do Estado, a região passou a ser alvo de explorações, vinculadas, principalmente, à construção das Usinas Hidrelétricas de Energia (UHEs) e das Pequenas Centrais Hidrelétricas (PCHs), em função da abundância hídrica da região. Por volta dos anos 90 foram projetados 15 empreendimentos de barragens, sendo seis especificamente para a bacia do Rio Doce, reflexo de projetos pensados desde a década de 60 por empresas privadas e estatais (ZHOURI e ROTHMAN, 2008). Além disso, o território da Zona da Mata Mineira vem sendo marcado pela disputa pelo minério. Segundo Rothman (2008) há informações que apontam para as primeiras sondagens de mineração na Zona da Mata Mineira em 1982, configurando, dessa forma, numa conjuntura sociopolítica favorável para emergência de conflitos em torno do controle e da gestão de recursos naturais na região.

Nesse sentido, estudar a atuação dos movimentos sociais no campo, sobretudo pelo viés teórico da Ação Coletiva, se torna um importante instrumento para entender e analisar diversos episódios da organização de agricultores em conjunto com a Igreja Católica no Brasil. Para tanto, este artigo apresenta um resumo das principais contribuições teóricas sobre a temática, bem como intenta apresentar e classificar algumas estratégias de mobilizações das organizações eclesiais de base junto ao Movimento dos Atingidos por Barragens (MAB) e aos agricultores na região da Zona da Mata Mineira, que ao longo dos anos vive num contexto de luta e resistência contra as barragens e contra os projetos de mineração. 


\section{REVISÃO BIBLIOGRÁFICA}

A literatura que busca analisar e conceituar os movimentos sociais, bem como os padrões de Ação Coletiva são diversas e dinâmicas ao logo do tempo. Vão desde estudos de grandes revoluções, como a Revolução Francesa (1789-1799), por exemplo, até estudos do fenômeno dos Rolezinhos nas grandes capitais do Brasil, que consistem em encontros de jovens - mormente, pobres das periferias - que marcam os Rolezinhos em Shoppings Centers pelas redes sociais, sobretudo pelo Facebook. É de se notar que os movimentos que deram origem a Revolução Francesa em 1789, os instrumentos utilizados e os objetivos das ações se diferem em muito das organizações do Rolezinhos ocorridas no final de 2013 e início de 2014 no Brasil. Na primeira ocorreu o uso de armas e o objetivo era de uma revolução completa num país, enquanto na segunda, o objetivo é a socialização e o reconhecimento de jovens da periferia, que em sua maioria só buscavam a diversão que estava em moda na época. Portanto, os métodos e conceitos utilizados para analisar esses fenômenos de Ação Coletiva devem ser diferentes.

Outrora, as análises que tentavam compreender os movimentos sociais antes de 1960-70 se pautavam nas teorias clássicas marxistas e funcionalistas, principalmente. As mobilizações coletivas nessa época eram concebidas como irracionais fruto de uma frustação individual ou como destaca Alberto Melucci (1989, p. 50) a "[...] ação coletiva era tratada ou como um feito de crises estruturais ou contradições, ou como uma expressão de crenças e orientações compartilhadas". Destacavam-se, de acordo com o sociólogo francês Alain Touraine, os movimentos sociais baseados nos conflitos produtivos, manifestados pela organização e ação dos trabalhadores em sindicatos. Nessa época, marcada pela sociedade industrial, o movimento operário seria o ator principal inserido no conflito industrial, inerente ao processo de Revolução Industrial Europeia. Em suma, os tipos de análise priorizavam as lutas de classes tendo como parâmetro os processos macroestruturais.

Neste bojo de concepções, anteriores a 1960, a socióloga Maria da Glória Gohn (1997) destaca em seus estudos cinco correntes atinentes às teorias clássicas sobre os movimentos sociais: A Escola de Chicago, as teorias de massa, a abordagem sociopolítica, o comportamento coletivo sobre a ótica do funcionalismo e as teorias organizacionais-comportamentalistas:

Os estudos da (I) Escola de Chicago durante quarenta anos (1910-1950) exerceu forte influência sobre a sociologia da época, afirma Maria da Glória Gohn. Tinha como objetivo principal de estudo a interação entre o indivíduo e a sociedade, assumindo que o primeiro era dotado de criatividade, passível de uma análise psicossocial - comportamentos e reações humanas. Em verdade, a importância dos postulados da Escola de Chicago para entender as mobilizações sociais da época se daria especialmente pela concepção de mudança social, que passava, por consequência, pela perspectiva de reforma social. Entretanto, a reforma social profícua só aconteceria com a presença de um líder, que através de seus exemplos de vida agregaria outros sujeitos de forma solidária, possibilitando a transformação social. Nesse sentido, a Escola de Chicago, em epítome, remeteria a dois pontos básicos para retratar o efeito da mudança social: a educação e a criação de instituições. A educação neste caso seria a grande fomentadora de estratégias para a sobrevivência no clima de conflitos e crises nas grandes cidades. Assim, os movimentos sociais, por sua vez, era fruto de comportamentos coletivos conflituosos, sobretudo, aqueles originados das multidões. Os líderes então exerciam o papel de 
apaziguadores dos conflitos, ou seja, não eram os responsáveis pelo surgimento das Ações Coletivas.

Cabe ressaltar, no entanto, que o grande tributo para as análises dos movimentos sociais nessa época veio do interacionismo simbólico de Hebert Blumer. Suas contribuições teóricas desenvolvidas entre as décadas de 20 e 30 - posteriormente retomadas nos anos 90 - trazem elementos advindos da psicologia social, principalmente. Para essa vertente de análise o interacionismo simbólico contribui de forma essencial a medida que possibilita a compreensão do modo como [...] os indivíduos interpretam os objetos e as outras pessoas com os quais interagem e como tal processo conduz o comportamento individual em situações específicas" (CARVALHO, BORGES e RÊGO, 2010, p.148). Sob a perspectiva prática, as motivações para o surgimento dos movimentos sociais, apesar de vir do exterior - podendo inclusive ser de ordem cultural - é no plano individual e no psicológico que elas se materializam.

A corrente teórica derivada dos (II) estudos de massa intentava analisar os comportamentos coletivos sobre a édige da anomia e das condições estruturais de carências e privações. Pode-se, com algum cuidado analítico, entender que grupos sociais que possuem seus direitos e identidades violadas caminham para episódios de revolução (McADAM, TARROW, TILLY, 2009). São formas predominantemente irracionais de grupos coletivos. Assim, para alguns teóricos da época, os movimentos sociais foram analisados como movimentos revolucionários, ou em outros dizeres, mobilizações de massa que visavam tomar o poder de um Estado antagônico (ALEXANDER, 1998).

Quanto a (III) abordagem sociopolítica, surgida nos anos 50, sob o clima do "silêncio" da Guerra Fria, o rumor do momento era de revolução e reforma. Com efeito, a discussão sobre movimentos sociais, para os estudiosos dessa corrente, soava como sinônimo de reivindicações partidárias. De orientação marxista, o teórico da vez era o alemão Rudolf Heberle que propunha em seus estudos articular a problemática das classes sociais e das relações sociais de produção. Segundo Maria da Glória Gohn (1997, p. 39) no que concerne as origens e motivações dos movimentos sociais Rudolf Heberle não se diferenciou muito da corrente anterior. "Os movimentos seriam sintomas de descontentamento dos indivíduos com a ordem social vigente e seus objetivos principais seriam mudança dessa ordem social".

A quarta teoria clássica se refere ao comportamento coletivo sob a ótica do (IV) Funcionalismo, que é, em síntese, uma mistura das abordagens da Escola de Chicago e da teoria de ação social do norte-americano Frederick Parsons. A teoria parsoniana trouxe a discussão elementos como normas, papéis, estrutura, função-equilíbrio e diferenciação estrutural, sendo que este conjunto de fatores resultaria na teoria do sistema social. Dessa forma, a aplicação dessa teoria aos movimentos sociais se manifesta quando há um cenário de irracionalidade em oposição a ordem racional vigente. Dessa forma, em sociedades bem integradas e estáveis com poucas tensões sociais haverá pouco surgimento de movimentos sociais, isto é, este fenômeno é típico de sociedades desorganizadas (GOHN, 1997).

Destarte, o funcionamento e sua ideia de estratificação social é a matriz de análise desta corrente. Nesse sentido, Neil Smelser, principal propagador das concepções teóricas de Frederick Parsons, retém em seus estudos algumas condicionantes da teoria estrutural necessária para a emersão dos movimentos sociais: 
[...] condutividade estrutural: organizações da sociedade podem facilitar a emergência de interesses conflitantes; filtros estruturais: a condutividade da estrutura social para conflitos potenciais leva à percepção de que os interesses em conflito, de fato, existem; crescimento e difusão de um sistema generalizado de crença: ideologia como uma visão compartilhada da realidade que redefine a ação social e serve como guia do comportamento; eventos precipitantes: dentro ou fora da estrutura social; atividades organizacionais: que transformam o potencial para a ação em ação efetiva; operação de controle social: resposta de outros na sociedade, tais como contra movimentos ou autoridades governamentais que alteram as condições estruturais ou suprimem o movimento (MISOCZKY, FLORES, SILVA, 2008, p.3).

Segundo Maria da Glória Gohn, Neil Smelser afirma que os movimentos sociais são munidos de ações irracionais, respostas cognitivas [inadequadas] para as tensões estruturais decorrentes da modernização. Assim, a abordagem Funcionalista tem como pressuposto fundamental o funcionamento de novas crenças e como estas interferem no comportamento coletivo.

Por fim, a última teoria clássica mapeada por Maria da Glória Gohn se refere as (V) teorias organizacionais comportamentalistas. Essa teoria, pouca solidificada na época, não criou de fato uma teoria específica sobre os movimentos sociais, assim como as contribuições derivadas dos estudos de massa apresentadas anteriormente. No entanto, constitui estudos importantes para 0 entendimento dos movimentos sociais. Baseado nos estudos de Max Weber sobre a burocracia intentou entender comportamentos coletivos agrupados em organizações. É importante ressaltar que as teorias organizacionais comportamentais foram importantes para a transição das teorias clássicas para a Teoria de Mobilização de Recursos nos Estados Unidos, posterior a década de 60.

Não obstante às teorias clássicas supracitadas, o filósofo alemão Jürgen Habermas aponta em seus estudos que os conflitos derivados da relação capital-trabalho, típica do século XIX é freado pelo Estado. O custo, entretanto, seria uma hipertrofia do Estado, ou seja, este passou a assumir um novo papel na sociedade pós-industrial, tendo como tarefa primordial a regulação da produção e do mercado (GOSS e PRUDENCIO, 2004; ALONSO, 2009). Nesse sentido, o conflito do mundo do trabalho toma direções culturais da vida em sociedade e as mudanças no mundo capitalista retratam novas motivações para a emersão de movimentos sociais os,

[...] conflitos sociais saem do tradicional sistema econômico-industrial para áreas culturais: eles afetam a identidade pessoal, o tempo e o espaço na vida cotidiana, a motivação e os padrões culturais da ação individual. Os conflitos revelam uma mudança maior na estrutura dos sistemas complexos e novas contradições parecem, afetando sua lógica fundamental. Por um lado, sistemas altamente diferenciados produzem cada vez mais e distribuem recursos pela individualização, pela auto-realização, por uma construção autônoma das identidades pessoais e coletivas (MELUCCl, 1989, p. 58).

A partir de então surgem três novas concepções, baseadas na racionalidade e, por consequência, em contraposição a irracionalidade das teorias anteriores: Teoria da Mobilização de Recursos, Teoria do Processo Político e a Teoria dos Novos Movimentos Sociais. A Teoria da Mobilização de Recursos, de origem norte-americana, procurou entender os movimentos sociais a partir da interação entre a disponibilidade de recursos e as estruturas disponíveis para se 
organizarem em uma organização formal. Um dos principais divulgadores e teórico dessa corrente foi Mancur Olson, que teve como principal inovação relacionar os movimentos sociais aos grupos de interesses, isto é, a prática coletiva se dava segundo o interesse de possíveis ganhos e benefícios, feitos sob o cálculo extremamente racional que implica em decisões políticas, morais e econômicas para os indivíduos participantes (JUNIOR, 2007). Em outras palavras a Teoria da Mobilização de Recursos deu ênfase na racionalidade e na organização, negando, com feito, as concepções estritamente ideológicas.

A Teoria do Processo Político, por sua vez, embora surgida também entre os teóricos norte-americanos, compreende casos europeus em sua análise. Possui, além disso, como fator preponderante o enquadramento macro-histórico e refuta a economia como chave explicativa dos movimentos sociais, pois enfoca elementos como a política e a cultura na explicação dos fenômenos (ALONSO, 2009). Assim, dois conceitos se tornaram importantes para a análise dessa corrente teórica: Estrutura de Oportunidades Políticas e Estrutura de Mobilizações.

O conceito de Estrutura de Oportunidade Política está comumente presente nos estudos do sociólogo Sidney Tarrow. Este autor considera que existe determinadas oportunidade políticas que possibilitam o surgimento de movimentos sociais, abrindo ou criando novos canais para expressão de reivindicações, ou seja, ocorrem mudanças nas dimensões formais e informais do ambiente político (MELUCCl, 1989). A Estrutura de Mobilização complementa de certo modo o conceito anterior, pois dizem respeito às diversas estratégias de engajamento em uma Ação Coletiva, isto é, evidenciam as formas de atuação do movimento social na prática, com seu repertório tático, formas de organização particular, além das estruturas físicas utilizadas para mobilizações, tais como salões paroquiais, sindicatos, associações, mesmo que não seja a priori o objetivo desses espaços (MCCARTHY, 1996 apud OLIVEIRA e ROTHMAN, 2008).

Charles Tilly - um dos grandes nomes da sociologia do século XX, em particular da sociologia política - contribuiu de forma semelhante para a Teoria do Processo Político quando destaca em seus trabalhos o conceito de Repertório de Ação Coletiva. Os repertórios seriam um conjunto de ações dos movimentos sociais, fruto de uma expressão da interação histórica e atual dos movimentos que visam determinada mudança. Surgem quando existe uma estrutura de oportunidade propícia que determina também o repertório utilizado pelos atores envolvidos ou quando estes precisam criar novas estratégias que comporão o repertório. Há, ademais, um conflito no que diz respeito ao uso de repertórios inovadores ou tradicionais. Se por um lado o “[...] uso repetido do mesmo repertório diminui sua eficácia instrumental e, desta forma, encoraja a inovação tática [...]", por outro "[...] os repertórios têm também uma função expressiva cuja lógica encoraja a persistência em vez da mudança [...]", isto, pois, repertórios convencionais, usados ao longo dos tempos dentro de um grupo só ganham tal status por serem considerados profícuos e, portanto continuam vigentes apesar das vantagens da inovação (McADAM, TARROW, TILLY, 2009, p. 25).

Tanto a Teoria da Mobilização de Recursos, quanto a Teoria dos Processos Políticos não estavam salvas das críticas da época. Através das contribuições de teóricos como Alain Touraine, Jürgen Habermas e Alberto Melucci surge a vertente europeia denominada Teoria dos Novos Movimentos Sociais. Em contraposição a Teoria de Mobilização de Recursos e a Teoria de Processos Políticos, Alberto Melucci (1989) afirma que estas concepções teóricas possuem problemas do "por que" e de "como", respectivamente. A primeira se limitaria no que tange a explicação dos motivos do acontecimento da mobilização coletiva, pois veem a ação como simples dados e não conseguem explicar, por consequência, seus significados e orientações. A 
segunda, por sua vez, não explicaria como os fenômenos acontecem, isto é, apenas evidencia o conflito potencial para a emersão de uma Ação Coletiva, contudo, não considera a ação concreta e nem os atores envolvidos. Para o autor deve haver uma interação entre objetivos, recursos e obstáculos ao se analisar a ação, tendo em vista como a orientação intencional dos grupos sociais se configura dentro de um sistema de oportunidades e coerções. Sendo assim, a mobilização de um grupo ou, em outras palavras, os movimentos sociais são sistemas de ações que operam num campo sistêmico de limites e possibilidades.

A Teoria dos Novos Movimentos Sociais, também balizada em uma análise macrohistórica, se delimitaria então como formas particulares de organização coletiva, voltadas para grupos ou minorias de coletivos maiores. Seu grande objetivo estaria em atingir demandas da vida cotidiana com um viés simbólico, principalmente, ou seja, cuidava de relações no âmbito do reconhecimento de identidades coletivas ou de estilo de vida. De modo peculiar, suas ações não tinham como alvo o Estado, mas setores da Sociedade Civil, almejando mudanças culturais de longo prazo sendo que esta é uma das características principais dos novos tipos de mobilizações sociais. Em síntese a Teoria dos Novos Movimentos Sociais deu prioridade aos elementos simbólicos e cognitivos, rejeitando (ou dando menor destaque) aos aspectos do ambiente político, dos interesses e recursos inerentes a prática da Ação Coletiva (ALONSO, 2009).

A partir da década de 90, tendo em vista diversas críticas, mas, mesmo assim, abarcando várias concepções conceituais [fragmentadas e adaptadas] de outrora, surgiram novas formas de definições dos movimentos sociais. Houve críticas de que a Teoria da Mobilização de Recursos explica mal as microfundações de recursos e sua analogia com uma organização empresarial seria malograda. Quanto a Teoria de Processos Políticos incidia a crítica de que o conceito central de Estrutura de Oportunidades Políticas seria demasiadamente abrangente e, com efeito, pouco explicativa. E, quanto a Teoria dos Novos Movimentos Sociais predominou a crítica de que não considera a dinâmica política-institucional e de que o conceito de Identidade Coletiva ora tramita por uma identidade social concreta, ora se define como uma ideia filosófica, culminando em um conceito vago. Dessa forma, um novo curso do conceito de movimentos sociais se projetou, conforme destaca o sociólogo americano Mario Diani (1992, p.1 apud ALONSO, 2009). A ideia passa ser conciliar teoria e metodologia, evidenciando dimensões estratégicas e simbólicas da Ação Coletiva. Assim, os movimentos sociais a partir de 1990 consistem em "[...] redes de interações informais entre uma pluralidade de indivíduos, grupos e/ou organizações, engajadas em conflitos políticos ou culturais, com base em identidades coletivas compartilhadas" (p. 73).

Não obstante as explanações acima, o que nos pareceu mais convincente, em termos de análise dos processos de Ação Coletiva para este estudo, são as concepções e categorias teóricas incutidas na Teoria do Processo Político, com passos cuidadosos ao encontro da Teoria dos Novos Movimentos Sociais. Buscamos ênfase - importa destacar - nos conceitos de Repertorio de Ação Coletiva de Charles Tilly, na Estrutura de Oportunidades Políticas e na Estrutura de Mobilizações pela sua aplicabilidade metodológica, tendo em vista o fenômeno estudado. Retrata-se, então, que não foi possível, nem intenção, comprar o pacote fechado de uma determinada corrente teórica, pois o caminho escolhido foi a adoção de conceitos independente de uma época ou autor específico. 


\section{METODOLOGIA}

Este trabalho é fruto do investimento inicial dos autores em um projeto de mestrado ligado ao Departamento de Economia Rural da Universidade Federal de Viçosa. O projeto busca entender os processos de Ação Coletiva na Zona da Mata Mineira em intercessão com a Arquidiocese de Mariana, Minas Gerais, sobretudo os que possuem convergência com a ala progressista da Igreja Católica. Destarte, visando uma investigação histórica dos episódios de resistência na região surgiram os primeiros resultados apresentados neste artigo.

Os métodos para coleta de dados consistiram na pesquisa bibliográfica e documental a partir do final da década de 80. De acordo com Gil (2002) a pesquisa bibliográfica intenta buscar informações em materiais já elaborados, como livros e artigos científicos. Além da vantagem de permitir uma ampla cobertura do fenômeno estudado, é indispensável para entender processos históricos. A pesquisa documental, por sua vez, se assemelha a pesquisa bibliográfica, contudo busca fontes que não receberam nenhum tratamento analítico. Dessa forma utilizamos matérias de jornais, banco de dados de instituições de pesquisa e coleta de fotos.

Quanto a análise dos dados, foram feitas com base na revisão de literatura e na categorização para linhas de análises. Isto é, projetou-se um cotejo entre os episódios de mobilização e a abordagem teórica escolhida, possibilitando assim uma construção histórica do surgimento e consolidação dos movimentos eclesiais na região, mapeando inclusive alguns atores sociais no percurso. A partir de então dividimos em três categorias de resistência: técnicocientífico, enfrentamento direto e educação-informação.

\section{RESULTADOS E DISCUSSÕES}

\subsection{Estrutura de Oportunidade Política: A Teologia da Libertação}

Evidenciamos inicialmente as principais características das Estruturas de Oportunidades Políticas que possibilitaram a consolidação de uma aliança entre a vertente da Igreja Católica Progressista e o Movimento dos Atingidos por Barragens na região da Zona da Mata Mineira, havendo inclusive momentos difíceis de separar o que foi um e o que foi outro, tendo em vista que por vezes as identidades se misturavam. Isso se dava, pois membros ligados inicialmente a Igreja Católica hora se identificavam como tais, hora se identificavam apenas como Movimento. Mas, na maioria das vezes houve um posicionamento claro da Igreja em favor da defesa dos atingidos, mesmo que por vezes alguns membros que estavam inseridos na militância não podiam responder em nome da Instituição, levando em consideração a hierarquia altamente respeitada dentro da Igreja. No entanto isso nem sempre foi assim. A Arquidiocese de Mariana foi durante muito tempo tida como uma das mais conservadoras do Brasil e não havia, com efeito, um apoio por parte da cúpula para com os movimentos de mobilização no campo ocorridas em finais da década de 80. A entrada do bispo Dom Luciano Mendes de Almeida apresentado por muitos como uma adepto da Teologia da Libertação - em 1988 na Arquidiocese foi de extrema importância para uma mudança nas Estruturas de Oportunidades Políticas na região.

De acordo com Oliveira (2005), apesar do grande número de dioceses e arquidioceses espalhadas pelo Brasil, a Arquidiocese de Mariana merece reiterada atenção. A vinda de Dom 
Luciano e sua locação como arcebispo de Mariana, no lugar de Dom Oscar estaria inserida num contexto de articulação maior que tinha como objetivo frear a atuação religiosa progressista de São Paulo. A Arquidiocese de São Paulo, maior jurisdição eclesiástica do Brasil, era comandada na época pelo cardeal Dom Paulo Evaristo Arns que lutou e influenciou em diversas resistências contra a Ditadura Militar. Dom Paulo Evaristo tinha por intenção que Dom Luciano, bispo auxiliar da arquidiocese de São Paulo, fosse seu sucessor, entretanto ocorreu sua nomeação para Arquidiocese Mariana a qual foi transferido (OLIVEIRA, PAGNOSSA e ZANGELMI, 2011). Este tipo contextualização se torna importante para a análise dos movimentos surgidos na base, tendo em vista que existe um panorama de conflito entre os defensores da Teologia da Libertação e defensores de uma igreja tradicional, menos convergentes com as questões políticas. Em um email $^{2}$ direcionado a Dom Pedro Casaldáliga, o teólogo e professor da Diocese de Lorena, Felipe Aquino $^{3}$, fez duras críticas aos Teólogos da Libertação incluindo Dom Luciano.

Lamento profundamente o seu artigo A VERDADE, PILATOS, É... onde o sr. mostra que apesar de já advertido cordialmente pelo Vaticano continua incorrigível, envenenando o povo com a teologia da libertação, que aniquila a verdadeira fé, subverte a salvação soteriológica como disse o então Ratzinger. [...] Por favor, não descaracterize a viagem do nosso Pastor, do "Joseph de Deus" que vem a nós. Não jogue o povo de novo contra ele e contra a Igreja, mais uma vez como fez duramente com João Paulo II. D. Casaldáliga, D. Paulo Arns ja está descansando embora entre nós, tambem D. Luciano Mendes, D. Ivo, D. Hipólito...um a um dos que erraram o caminho, o Espirito Santo está retirando do palco (Professor Felipe Aquino, 2007).

A afirmação "erram o caminho, o Espírito Santo está retirando do Palco" com referência a Dom Luciano trouxe revolta e indignação a outros padres e leigos que acompanharam o histórico de mais de quinze anos de lutas sociais de Dom Luciano na Arquidiocese de Mariana. Padre Geraldo Martins, assessor de comunicação e informática da Conferência Nacional dos Bispos do Brasil (CNBB), retrucou em uma carta ${ }^{4}$ ao teólogo Felipe Aquino. Segundo o assessor da CNBB estava surpreso com o fundamentalismo e ódio que o teólogo possuía para com aqueles que coadunavam com a Teologia da Libertação.

[...] Que o senhor faça opção por uma eclesiologia alienada e alienante, alimentada por uma cristologia, da mesma forma, desencarnada e a-histórica, a gente compreende e aceita. Agora, desqualificar com linguagem arrogante, xenófoba, fundamentalista, homens que fazem e fizeram de sua vida, tal como Cristo, um aniquilamento em favor dos pobres e excluídos, é imoral, antiético, anticristão. $O$ amor deles pela Igreja de Cristo é de tal profundidade que ultrapassou sua capacidade de compreendê-los. Talvez isso o tenha deixado confuso, perturbado, levando-o a escrever o que escreveu. [...] Como o senhor está bastante desinformado sobre a biografia dos que afirma terem "errado o caminho", envio, anexos, alguns depoimentos e testemunhos acerca da vida e da obra de dom Luciano com quem convivi 18 anos na diocese primaz de Minas Gerais. Sinto, portanto, o dever imperioso de dizer-lhe que, ao ofender dom

\footnotetext{
${ }^{2}$ Para averiguar o conteúdo dos e-mails acessar: < http://www.oraetlabora.com.br/mail_recebidos/carta_de_ felipe_aquino_para_d.htm>. Acesso em 27 de dezembro de 2014.

${ }^{3}$ Professor Felipe Aquino é famoso e respeitado entre os teólogos da Igreja. Possuindo mais de 50 livros tem um programa em horário nobre na emissora televisiva Canção Nova, além de fazer palestras por todo o Brasil.

${ }^{4}$ Idem nota 2.
} 
Luciano, o senhor ofendeu toda a Arquidiocese de Mariana e a Igreja do Brasil. (Padre Geraldo Martins, 2007).

Em outro e-mail ${ }^{5}$ direcionado ao Professor Felipe Aquino, o Padre José Antônio de Oliveira, também da Arquidiocese de Mariana, retratou que o professor não conhecia nem um por cento do que fez e do que foi Dom Luciano, pois, caso contrário, não citaria seu nome com tanta petulância e desrespeito.

Quem conhece não teria a coragem de escrever o que você escreveu. Convivi por mais de 15 anos com dom Luciano. Sou testemunha do seu amor incondicional à Igreja, a Jesus Cristo, aos pobres e sofredores, aos presidiários, aos enfermos. Sou testemunha das noites passadas em claro, das viagens de ônibus, da presença nos lugares mais simples. Sempre mostrou ao povo um Deus mãe, como sempre enfrentou com coragem profética os que exploram e oprimem. Já com câncer, pouco antes de ser internado pela última vez, se juntou ao povo que lutava por energia elétrica mais barata, para enfrentar os soldados que atacavam aquela gente simples a cavalo, com armas e cachorros. Se você conhecesse um por cento do que fez e foi dom Luciano, não teria a petulância e a falta de respeito de dizer que o Espírito Santo o tirou do palco. Isso dói lá no fundo do coração, porque é um insulto ao próprio Deus, é pisotear a memória de alguém que deixou uma vida de conforto, no seio de uma família abastada, para viver pobre e pelos pequenos. É espezinhar a honra de alguém que é venerado por tantos e tantos que o veneram (Padre José Antônio, 2007).

Pois bem, ser ou não adepto da Teologia de Libertação foi o foco da discussão que tangenciou os movimentos progressistas na Arquidiocese. Todavia, o fato é que os adeptos da Teologia têm maior propensão a mobilização e organização de comunidades pobres no meio rural. O próprio Dom Luciano, em uma entrevista concedida ao programa Roda Viva ${ }^{6}$ ressaltou a importância dessa vertente da Igreja Católica.

O que eu posso Ihe dizer é que a Teologia da Libertação, na minha pobre análise, ela ainda vai dar todos os seus frutos. Mas ela é mais conhecida por aqueles que podem ler, que podem refletir, não é algo que entrou assim em todos os níveis da pregação cristã no Brasil. Sobretudo para os mais simples, talvez alguns aspectos da Teologia da Libertação, mas ela é ainda algo que é mais acolhido pelos estudiosos, mais pelo menos como tema de reflexão (Dom Luciano, entrevista cedida ao programa Roda Viva, 1991).

$\mathrm{Na}$ base, as comunidades eclesiais se formaram de acordo com os princípios de uma igreja progressista, voltada para as desigualdades sociais no campo. Aproveitaram, outrossim, das condições favoráveis da Estrutura de Oportunidades Políticas em voga. Destarte, no início dos anos 90, inspirados em mobilizações feitas na Diocese de Caratinga, padre Antonio Claret, padre José Geraldo, padre João do Carmo e um grupo de leigos reuniram comunitários rurais a fim de organizar Comunidades Eclesiais de Base (CEBs). De acordo com o Padre Claret, a Arquidiocese de Mariana não utilizava o "Roteiro das CEBs" que consistia num instrumento de orientação para organização das comunidades rurais. Hoje, no entanto, o roteiro de reflexão é uma prática

\footnotetext{
${ }^{5}$ Idem nota 2.

${ }^{6}$ Para ver toda a entrevista: < http://www.rodaviva.fapesp.br/materia/734/entrevistados/dom_luciano_mendes_de _almeida_1991.htm> Acesso em 23 de dezembro de 2014.
} 
empregada por toda a Arquidiocese. "No entusiasmo de transformar a realidade, senti na pele que o processo de libertação só acontece quando se cria o clima favorável para que as pessoas sejam sujeito de sua libertação" (Padre Claret, 2004)7. Cabe ressaltar, que a organização das CEBs na época buscavam resolver carências sociais básicas como subnutrição de crianças, problemas de abastecimento de água as comunidades, escoamento da produção através da criação de pequenas associações, falta de ônibus para meio rural, dentre outros problemas. Posteriormente, as mobilizações se deram em função de grandes conflitos, principalmente.

\subsection{Estrutura de Oportunidade Política: Conflitos Socioambientais e redes de resistência}

A configuração agrária de Minas Gerais se difere de outros estados, sobretudo no que se refere ao predomínio de minifúndios. Assim, enquanto em outras regiões do Brasil a Igreja Católica Progressista reuniu esforços na luta pela Reforma Agrária, em Minas, os conflitos se deram em outras condições. A abundância hídrica da região e a grande demanda energética do país possibilitou a inclusão de diversos projetos de barragens na região. Este fato tem colocado em lado opostos, pequenas comunidades e grandes empresas privadas e, com efeito, resultando nos conflitos socioambientais. Os conflitos socioambientais ocorrem quando há uma disputa por recursos naturais, sua gestão ou apropriação. Em outras palavras, de acordo com antropólogo Paul Little (2004) os conflitos socioambientais consistem em "[...] embates entre grupos sociais em função de seus distintos modos de inter-relacionamento ecológico, isto é, com seus respectivos meios social e natural" (p.1).

Os conflitos sempre colocam em cena os impactos sociais e ambientais, atingindo diretamente diversas famílias rurais que são realocadas compulsoriamente por consequência de grandes extensões de terras que são alagadas para construção de barragens. Henri Acselrad (2010, p.7) corrobora que existe um agravante, pois os impactos ambientais e sociais são distribuídos de forma desigual "[...] atingido mais do que proporcionalmente as populações mais destituídas, de menor renda, populações tradicionais e grupos étnicos". São famílias que outrora dependiam da terra e do rio para viver, pescadores, garimpeiros, meeiros, que da terra e do rio retiravam quase tudo. Sem contar os impactos simbólicos, lembranças e laços comunitários perdidos, que não são indenizados no processo. Fica instaurado então um ambiente propício Estrutura de Oportunidades Políticas - para atuação dos movimentos sociais e, na Zona da Mata de Minas, foi marcada pela presença dos grupos eclesiais que se mobilizam em favor das comunidades atingidas.

Em um documento com vistas a obtenção do Prêmio Direitos Humano da Universidade Federal de São Paulo (USP), organizada pelo então Deputado Federal em 2004, César Medeiros, Padre Claret, aspirante ao título, retrata em suma como se deu o processo de formação de uma rede de resistência contra barragens na Zona da Mata Mineira e no Alto Rio Doce. Inicialmente não existia ainda o MAB na região. As primeiras movimentações se deram com o encontro entre o Padre Claret e o professor Franklin Daniel Rothman, da Universidade federal de Viçosa, por volta de 1995. O professor Franklin, recém-chegado de uma pesquisa no sul do Brasil com atingidos por barragens deu início, juntamente com outros militantes, ao Núcleo de Assessoria às Comunidades Atingidas por Barragens (Nacab). O Nacab, por sua vez, contava com o apoio de um membro da Comissão Pastoral da Terra (CPT) e do Padre Gilson, da paróquia de São Sebastião,

\footnotetext{
${ }^{7}$ Retirado do documento "Uma vida dedicada aos direitos humanos" confeccionado em 2004.
} 
Ponte Nova, Minas Gerais. Padre Claret destaca dois grandes embates que foram responsáveis para a consolidação da rede de resistência: o projeto da barragem de Pilar, consórcio entre a FIAT e ALCAN e a barragem de Emboque, de responsabilidade da Companhia Força e Luz Cataguases Leopoldina.

O projeto Pilar, que teria sua implantação no Rio Piranga atingiria mais de 300 famílias, sobretudo agricultores familiares dos municípios de Guaraciaba e Ponte Nova, Minas Gerais. Contudo, a luta e resistência por mais de cinco anos das comunidades impediram a concretização deste projeto em 1999. Quanto ao processo de resistência contra a barragem de emboque, num primeiro momento, a organização não foi tão profícua com o potencial de barrar as obras, não obstante, muitas das condicionantes que não foram cumpridas na época, mas que foram cumpridas posteriormente se deu pela organização e persistência do povo. Na foto (Figura 1) abaixo pode ser visto o Padre Claret e o Padre Juquinha reunindo uma comunidade rural para um protesto popular no interior da Zona da Mata Mineira.

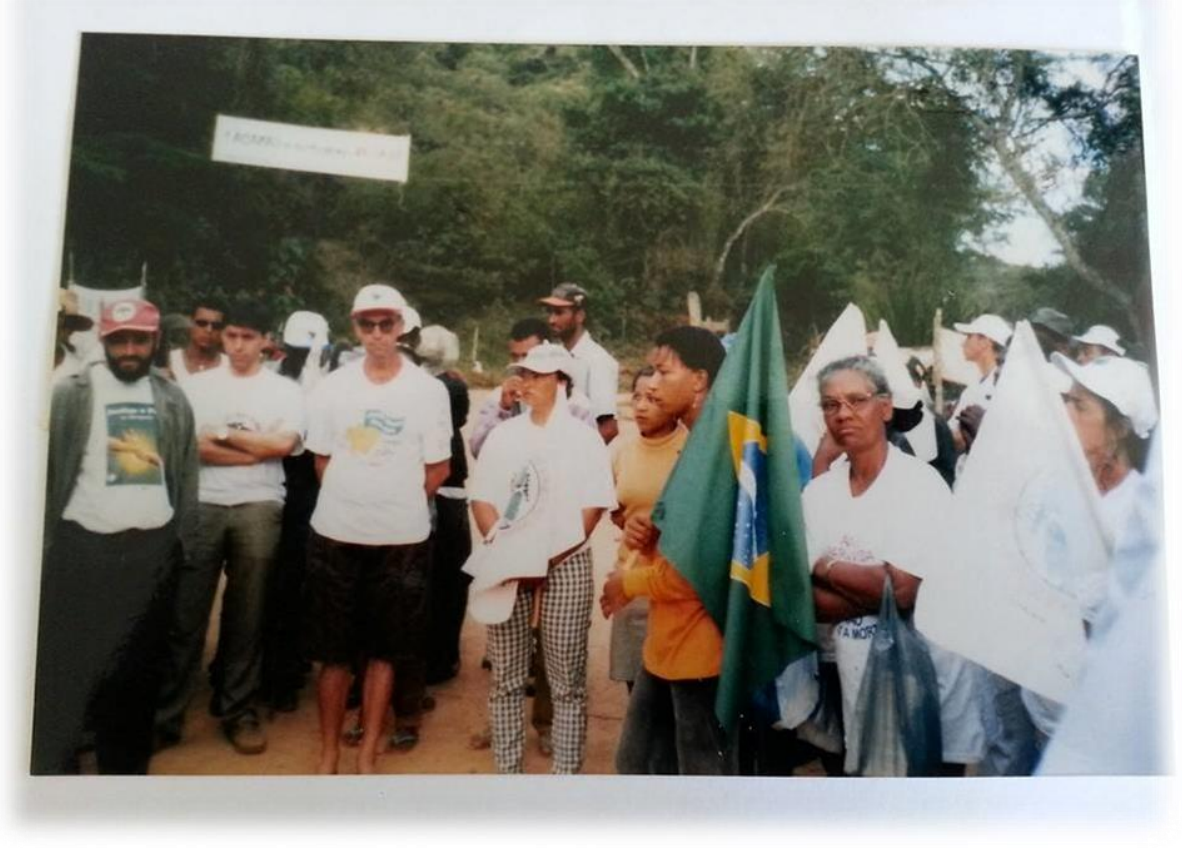

Figura 1 - Comunidade rural se preparando para uma intervenção Fonte: Acervo Nacab, 2014.

É importante destacar que os conflitos socioambientais e potenciais conflitos armam o palco para que os movimentos sociais atuem, incluindo os movimentos ligados a Igreja Católica Progressista. E é por isso que reiteramos o fato de constituírem uma Estrutura de Oportunidade Política. Nesse sentido, o Grupo de Estudos em Temáticas Ambientais (Gesta) vinculado a Universidade Federal de Minas Gerais (UFMG) realizou um mapeamento dos principais conflitos socioambientais no estado. Devido ao histórico de envolvimento de membros da Igreja Católica em grandes projetos de infraestruturas importa, portanto, explanar aqui alguns conflitos ${ }^{8}$ derivados dos projetos de hidrelétricas e de mineração, tal como podem ser vistos no Quadro 1, abaixo.

\footnotetext{
8 Segue o título dos conflitos de acordo com o mapeamento do GESTA. Para ver detalhes dos conflitos: <http://conflitosambientaismg.lcc.ufmg.br/observatorio-de-conflitos-ambientais/mapa-dos-conflitos-ambientais/.> Aceso em 29 de dezembro de 2014.
} 
Quadro 1 - Conflitos propícios à emersão de movimentos sociais em Minas Gerais (continua)

\begin{tabular}{|c|c|}
\hline $\begin{array}{l}\text { Conflitos ocasionados por empreendimentos de } \\
\text { mineração }\end{array}$ & $\begin{array}{c}\text { Conflitos ocasionados pela construção de Usinas } \\
\text { Hidrelétricas de Energia (UHEs) e Pequenas Centrais } \\
\text { Hidrelétricas (PCHs) }\end{array}$ \\
\hline Mobilização contra atividades minerárias em Belo Vale & Luta dos atingidos pela UHE Funil \\
\hline $\begin{array}{l}\text { Luta de moradores da comunidade Corumbá contra a } \\
\text { mineração de granito }\end{array}$ & Barragem Hidrelétrica Retiro Baixo \\
\hline $\begin{array}{l}\text { Resistência e luta contra a instalação de projetos de } \\
\text { mineração de ferro nas microrregiões de Grão Mogol e } \\
\text { Salinas }\end{array}$ & Luta dos atingidos pela barragem de Irapé \\
\hline $\begin{array}{l}\text { Mineração de ouro em Riacho dos Machados e riscos de } \\
\text { contaminação da água em Janaúba }\end{array}$ & $\begin{array}{l}\text { Atingidos pela Barragem de Setúbal lutam por } \\
\text { melhorias em reassentamento }\end{array}$ \\
\hline $\begin{array}{l}\text { Quilombo e povoados do município de São Tiago lutam } \\
\text { contra Mamoré Mineração e Metalurgia Ltda }\end{array}$ & $\begin{array}{l}\text { Comunidades rurais das ilhas resistem quanto ao rumor } \\
\text { de instalação de uma barragem }\end{array}$ \\
\hline Movimento de resistência à mineração em Congonhas & $\begin{array}{l}\text { Resistência à construção de PCH's no curso da Bacia do } \\
\text { Rio Santo Antônio }\end{array}$ \\
\hline Resistência à mineração na Serra da Moeda & $\begin{array}{l}\text { Conflitos entorno da Barragem Norte da Mina de } \\
\text { Brucutu }\end{array}$ \\
\hline $\begin{array}{l}\text { Movimento contra expansão da Mina Tamanduá sobre a } \\
\text { Estação Ecológica de Fechos }\end{array}$ & $\begin{array}{l}\text { Atingidos pela Pequena Central Hidrelétrica }(\mathrm{PCH}) \\
\text { Fumaça }\end{array}$ \\
\hline Mineração em Itabira & Conflito Causado pela Barragem na Lagoa do Onça \\
\hline $\begin{array}{l}\text { Resistência à mineração da Anglo Ferrous Minas-Rio S.A. } \\
\text { em Conceição do Mato Dentro }\end{array}$ & Resistência à PCH de Pandeiros \\
\hline $\begin{array}{l}\text { Moradores de Caldas e Poços de Caldas lutam contra } \\
\text { impactos da mineração de urânio }\end{array}$ & Luta dos atingidos pela barragem de Irapé \\
\hline $\begin{array}{l}\text { Movimentos de moradores contra a mineração em } \\
\text { Abadia dos Dourados }\end{array}$ & Atingidos pela barragem de Murta \\
\hline Mineradora causa danos ambientais em Conselheiro Pena & Resistência dos Atingidos pela Barragem de Berizal \\
\hline $\begin{array}{l}\text { Movimento de resistência ao empreendimento Manabi } \\
\text { Morro do Pilar Minerais S/A }\end{array}$ & $\begin{array}{l}\text { Atingidos pela construção das barragens hidrelétricas } \\
\text { Batalha e Serra do Facão no Rio São Marcos, divisa } \\
\text { entre Minas Gerais e Goiás }\end{array}$ \\
\hline $\begin{array}{l}\text { Resistência contra a construção do mineroduto Minas - } \\
\text { Rio }\end{array}$ & $\begin{array}{l}\text { Construção de barragem gera conflito com atividade } \\
\text { pesqueira no rio Urucuia }\end{array}$ \\
\hline $\begin{array}{l}\text { Conflitos entre empresas de mineração de bauxita, } \\
\text { administração do Parque Estadual da Serra do Brigadeiro } \\
\text { e agricultores da região. }\end{array}$ & Dano causado pela Barragem de Arrozal \\
\hline
\end{tabular}

Fonte: Confeccionado a partir do mapa de conflitos do GESTA, 2014.

Ressalta-se que os conflitos mapeados são considerados como atuais - ou herança de episódios passados -, isto é, não retrata o histórico de resistência na região. Para muitos com a virada de século (pós 21) o cenário mudou. Houve uma menor propensão a construção de grandes projetos de infraestrutura, ao contrário da década de 90 que teve grande incidência e, com efeito, obrigou um maior número de mobilizações e resistência na região. Entretanto, há de se considerar nesse contexto o grande número de projetos de barragens pensados até 2027. De acordo com informações contidas na Avaliação Ambiental e Estratégica do Programa de Geração Hidrelétrica em Minas Gerais (PGHMG 2007-2027), realizada pelo Estado, estão previstas para Minas Gerais até 2027 a construção de 45 UHEs e 335 PCHs. Para o Governo os projetos se justificam a medida que haverá um aumento na demanda por energia nos próximos anos e, ademais, consiste no capital físico a ser investido no estado trazendo, por consequência, desenvolvimento socioeconômico para as regiões onde serão implantadas. Todavia, é contra este tipo de desenvolvimento almejado pelo Estado é que articulações de movimentos de resistências acontecem (FONSECA, OLIVEIRA e SOUSA, 2011, 2012). 
Quadro 2 - Conflitos propícios à emersão de movimentos sociais em Minas Gerais (conclusão)

\begin{tabular}{|c|c|}
\hline $\begin{array}{l}\text { Conflitos ocasionados por empreendimentos de } \\
\text { mineração }\end{array}$ & $\begin{array}{l}\text { Conflitos ocasionados pela construção de Usinas Hidrelétricas } \\
\text { de Energia (UHEs) e Pequenas Centrais Hidrelétricas (PCHs) }\end{array}$ \\
\hline $\begin{array}{l}\text { Articulação de movimentos sociais da zona da } \\
\text { mata contra mineroduto da Ferrous Resources }\end{array}$ & $\begin{array}{l}\text { Atingidos pela Barragem Candeias e Santo Antônio no Rio } \\
\text { Traíras }\end{array}$ \\
\hline Mina Gongo Soco & $\begin{array}{l}\text { Moradores de Itajubá lutam contra construção de barragens } \\
\text { secas }\end{array}$ \\
\hline \multirow{19}{*}{$\begin{array}{l}\text { Movimento contra mineração pela preservação } \\
\text { da Serra da Piedade }\end{array}$} & Impacto ambiental causado por Barragem em área de vereda \\
\hline & $\begin{array}{l}\text { Moradores cobram informações sobre construção da PCH Rio } \\
\text { Manso, em Itajubá }\end{array}$ \\
\hline & Luta contra a construção da PCH Aiuruoca \\
\hline & Luta dos atingidos pela UHE Funil \\
\hline & $\begin{array}{l}\text { Resistência às Pequenas Centrais Hidrelétricas (PCHs) no } \\
\text { município de Passa Tempo }\end{array}$ \\
\hline & $\begin{array}{l}\text { Movimento da Associação dos Pescadores de Nova Ponte pela } \\
\text { liberação da pesca profissional na represa da UHE de Nova } \\
\text { Ponte }\end{array}$ \\
\hline & $\begin{array}{l}\text { Luta Contra a Instalação de Pequenas Centrais Hidrelétricas } \\
\text { (PCHs) no rio Tijuco }\end{array}$ \\
\hline & $\begin{array}{l}\text { Atingidos contestam compensação ambiental pelas barragens } \\
\text { Amador Aguiar, do Consórcio Capim Branco Energia }\end{array}$ \\
\hline & Luta contra a construção de PCH no Rio Dourados \\
\hline & $\begin{array}{l}\text { Luta pela demarcação territorial da Comunidade Quilombola } \\
\text { dos Marques, atingidos pela PCH Mucuri. }\end{array}$ \\
\hline & Barragem Santa Clara \\
\hline & $\begin{array}{l}\text { Resistência a Pequenas Centrais Hidrelétricas no município de } \\
\text { Coroaci. }\end{array}$ \\
\hline & Conflitos Ambientais gerados pela construção da UHE Baguari \\
\hline & $\begin{array}{l}\mathrm{PCH} \text { gera conflito entre empreendedores e moradores dos } \\
\text { municípios de Alvarenga, Pocrane e Conselheiro }\end{array}$ \\
\hline & Conflitos Ambientais gerados pela UHE Aimorés \\
\hline & $\begin{array}{l}\mathrm{PCH} \text { Cocais Grandes gera conflito entre empreendedores e } \\
\text { atingidos no município de Antonio Dias }\end{array}$ \\
\hline & $\begin{array}{l}\text { Atingidos pela Usina Hidrelétrica Barra do Braúna lutam contra } \\
\text { deslocamento compulsório provocado pelo empreendimento }\end{array}$ \\
\hline & $\begin{array}{l}\text { Movimento dos Atingidos por Barragens denuncia } \\
\text { responsabilidade de usinas hidrelétricas em enchentes em } \\
\text { Ponte Nova }\end{array}$ \\
\hline & Movimento dos atingidos pela barragem de Candonga \\
\hline
\end{tabular}

\subsection{Estrutura de Mobilizações e Repertório de Ação Coletiva}

Como os movimentos se organizam e quais as possibilidades estruturais de atuação são elementos importantes para entender o histórico de resistência. No Brasil, existe um histórico quanto às estratégias de resistências utilizadas e de certo modo elas se convergem entre os movimentos sociais, seja em lutas na cidade ou no campo. Parecem existir metodologias e discursos comuns adaptadas aos contextos locais, mas quase sempre enviesadas por padrões de esquerda que orientam as ações políticas e culturais dos movimentos. Não é raro, portanto, que os movimentos sociais, principalmente aqueles originados das academias ou que tem lideranças que realizam o perfil de ação teórica e metodológica baseado em princípios ideológicos de autores como Karl Max, Paulo Freire, Antonio Gramsci, entre tantos outros. Existe então nesse 
sentido um grande embate entre a Igreja e os movimentos sociais, já que a primeira é contrária aos pressupostos socialistas e revolucionários - que diversos destes autores compactuam -, sobretudo se utilizar de algum tipo de enfretamento violento ou que possa estimular a violência em qualquer outro aspecto.

O próprio Dom Luciano em uma entrevista concedida a pesquisadores da Universidade Federal de Ouro Preto (UFOP), Minas Gerais, retratou alguns aspectos relativos as prioridades no processos de resistência, ressaltando, concomitantemente a necessidade de se criar espaços de diálogos entre a comunidade e representantes do empreendedor, incluindo além disso autoridades do Estado.

Três soluções apresentaram-se: a primeira é organizar o povo para que eles tenham condições de expressarem suas expectativas e essas organizações podem ser induzidas por um grupo, induzida por outro, até que houvesse uma consolidação, um fortalecimento das iniciativas propriamente populares passados alguns anos. [...] A segunda saída é realmente o diálogo com as entidades que promovem a construção de barragens. Esse diálogo nem sempre foi fácil, porque havia assessores que visitavam as famílias oferecendo indenizações, uma ou outra aceitava, outras não aceitavam; resultado: foi se criando uma espécie de confronto de fazer acontecer a barragem e a defesa dos direitos dos atingidos por barragens. Então, essa solução, embora viável, ela foi de difícil condução. E a terceira era o recurso à autoridade governamental nas suas diversas instâncias para arbitrar essa organização dos atingidos [Entrevista com Dom Luciano] (SILVEIRA, OLIVEIRA e FERREIRA, 2006, p.22-23).

Pensar o diálogo com o empreendedor nas organizações de base é algo inaceitável, tratado até mesmo como traição. Movimentos não se comunicam com empreendedor e isso é uma palavra de ordem. Assim, o movimento de base se orientará por vezes de forma contrária às sugestões do alto escalão da Igreja, mesmo que esta simpatize com o movimento progressista, adepto ou não da Teologia da Libertação. Isto é, estão, em verdade, convergentes com os objetos da ação que é a defesa dos direitos humanos, se divergem, porém, na forma como alcançá-los. Não obstante às estratégias de defesa das comunidades é possível mapear três tipos que se tornaram comuns ao longo da história de conflitos na região e afluem com outras experiências pelo Brasil, intituladas neste trabalho como: técnico-científico, enfrentamento direto e educaçãoinformação.

O processo de construção de grandes empreendimentos, desde a fase de planejamento até o cumprimento das condicionantes - pós funcionamento do projeto - junto as comunidades requer um conhecimento técnico muito grande, sobretudo no que concerne aos processos negociáveis ao longo de todo o conflito. O problema é que comunidades rurais, as quais seus moradores possuem baixos níveis de escolaridade, incluindo muitos que mal sabem assinar o próprio nome, tem sofrido sobremaneira por não possuir o métier científico necessário para lidar com as situações ao longo do conflito. Nesse contexto, a Igreja em aliança com outras organizações, como grupos universitários e ONGs, tem feito um papel importante neste campo de atuação. Configura-se então em um dos pontos de ação que tem dado alguns resultados satisfatórios, mesmo diante de uma grande assimetria de recursos tendo em vista o capital científico do empreendedor. 
Documentos técnicos, tais como os Estudos de Impacto Ambiental (EIAs) e os Relatório de Impacto Ambiental (RIMAs), instrumentos de difícil decodificação, são necessários para obtenção da Licença Prévia dos projetos e são responsáveis por delimitar ações futuras. Ali estão listados os principais impactos sociais e ambientais que incidirão sobre as comunidades, projetando, com efeito, medidas compensatórias para minimizar ou reverter em possibilidades de melhorias para as comunidades e para a região indiretamente impactada. Dessa forma, analisar o EIA/RIMA e identificar os principais erros, faz parte da estratégia de Ação Coletiva. Entretanto, este é apenas um exemplo dos diversos documentos que incorrem durante o processo, passíveis de entendimento por parte da comunidade.

Outra instância de projeção no processo de resistência - que é de certo modo técnicacientífica - se referem as audiências públicas. Digamos de certo modo, pois se configura como um espaço apenas consultivo, não deliberativo. Ainda sim, a presença e fala de membros da Igreja se torna importante, assim como na preparação para levar às comunidades para as audiências. Nos fragmentos abaixo, retirado de jornais da época, podem ser vistos alguns exemplos da participação de movimentos eclesiais nesses espaços.

[...] cada uma das entidades que defendem os interesses dos atingidos também tiveram 5 minutos para expressarem sua opinião. $O$ primeiro a se apresentar foi o padre Claret, representando as CEBs da Arquidiocese de Mariana. Segundo ele, "este é um jogo de forças. Força do poder (empreendedor) e força do povo que vai começando a entender a importância da organização" (FOLHA DE PONTE NOVA $^{9}, 2001$, audiência pública em Miguel Rodrigues, Minas Gerais).

[...] o padre Claret discorda e frisa decisão do MAB: exigir dos órgãos ambientais que só autorizem o enchimento do lago com o fim de "muitas pendências" [...] Há ênfase para problemas na obra da Nova Soberbo (cuja vila original será inundada) e várias reivindicações dos atingidos, com dramas que incluem um desaparecimento e uma morte. Neste caso o arcebispo [Dom Luciano] apela para as "questões humanitárias e de direito" (FOLHA DE PONTE NOVA, 2003, audiência pública em Belo Horizonte, Minas Gerais).

Outro ponto de Ação Coletiva que compõe o repertório constitui no enfrentamento direto, não num sentido de violência, mas suas mais variadas formas de embate com empreendedor, incluindo formas de enfretamento que são simbólicas, tal como a utilização do teatro, da dança e da música de conteúdo crítico. Ou, tida como mais enérgicas, aquelas formas de enfrentamento em que o número de pessoas participando faz toda diferença, a citar os acampamentos, as invasões e as passeatas, por exemplo. Mais uma vez a presença de membros da Igreja Católica em trabalho conjunto com outros movimentos sociais faz a diferença. Primeiro que, a experiência das organizações eclesiais de base é de suma importância para a mobilização do povo, incluindo ações e discursos baseados na bíblia, típico dos adeptos da Teologia da Libertação. Segundo, pois, a presença de líderes religiosos, em consonância com líderes locais é um fator essencial para a aglomeração de um grande contingente de pessoas necessário para a

\footnotetext{
${ }^{9}$ Os trechos de matérias de jornais contidas nesse trabalho é fruto de uma coleta de documentos junto ao Projeto de Assessoria às Comunidades Atingidas por Barragens (projeto de extensão ligado a Universidade Federal de Viçosa UFV) e junto ao Núcleo de Assessoria às Comunidades Atingidas por Barragens. Salienta-se que por vezes só existiam os recortes dos jornais, não sendo possível, por consequência, realizar a inclusão completa nas referências bibliográficas.
} 
prática coletiva. Eis, a seguir, alguns exemplos destes tipos de mobilização levando em consideração que seria impossível listar todos.

O processo da marcha foi se fortalecendo a partir da necessidade de denunciar a situação que vivemos e o tratamento que recebemos das empresas construtoras de barragens. As mobilizações organizadas nas regiões em função do Dia Internacional de Luta contra as barragens - 14 de março, não foram suficientes para as empresas atenderem nossas reivindicações [...] (JORNAL MOVIMENTO DOS ATINGIDOS POR BARRAGENS, 2004, p. 2).

Manifestação reúne produtores na Alcan. O protesto é contra a construção de uma Usina Hidrelétrica de Fumaça na região de Diogo Vasconcelos e Fumaça. A empresa está sendo acusada de obrigar produtores rurais a negociarem as terras [...] (JORNAL PONTO FINAL, 2001, p. 1).

Mais de duzentas famílias da comunidade do distrito de Miguel Rodrigues invadiram na segunda feira 29, o canteiro de obras da Usina Hidrelétrica de Fumaça [...] A Invasão está sendo comandada pelo Movimento dos Atingidos por Barragens com o apoio da Comissão Pastoral da Terra [...] (JORNAL PONTO FINAL, 2001, p.3).

Percebe-se que a escolha pela forma de enfrentamento obedece a fatores externos, mas ainda sim os grupos possuem uma maior autonomia sobre esse tipo de Ação Coletiva do que na forma anterior. Desde que tenha recursos disponíveis (incluindo, por vezes, recursos financeiros) e planejamento prévio estes tipos de ações são viáveis. São bem vindas, ademais, em datas especiais como datas religiosas ou em reuniões de órgãos ambientais, incluindo lugares públicos e movimentados, por exemplo, pois, para os movimentos sociais o ideal é atingir o máximo de visibilidade da sociedade no sentido de denunciar as injustiças que estão sofrendo. Nas Figuras 2 e 3, abaixo, podem ser vistos imagens da Romaria da Água e da Terra que aconteceu em Miradouro, Minas Gerais. A Romaria, organizada pela Diocese de Leopoldina e pela Comissão Pastoral da Terra é mais um exemplo de manifestação religiosa e popular que arrasta multidões de pessoas, sobretudo agricultores familiares devotos.

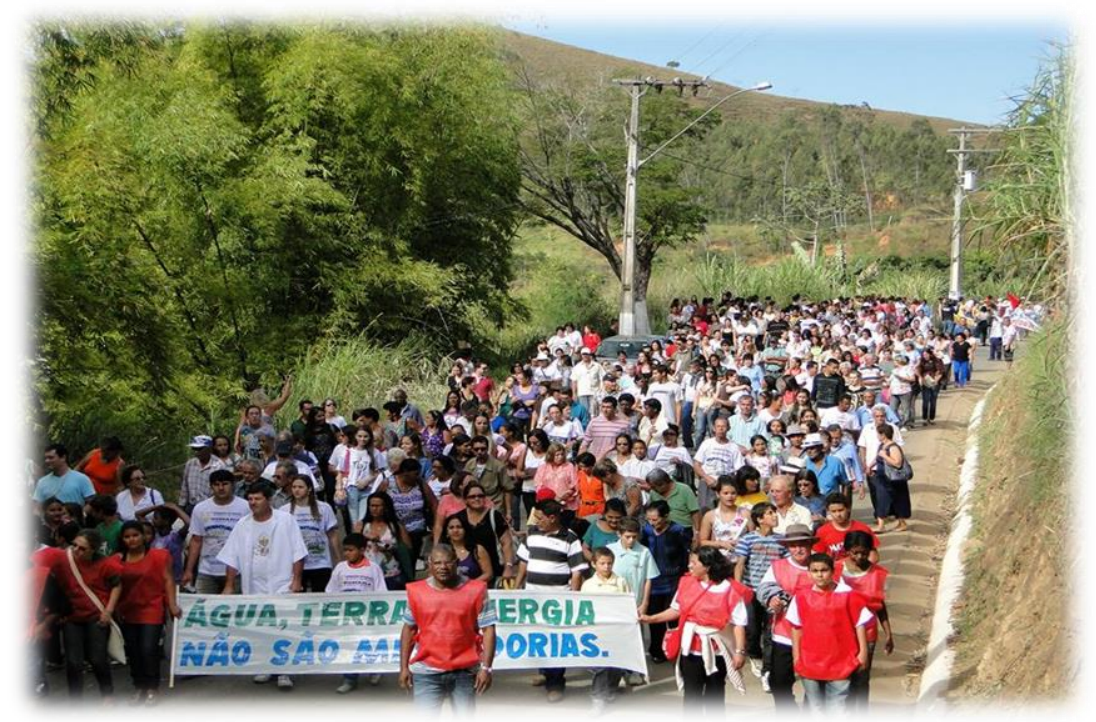

Figura 2 - Romaria dos Trabalhadores, caminhada de fé Fonte: Tribuna de Muriaé, 2013. 


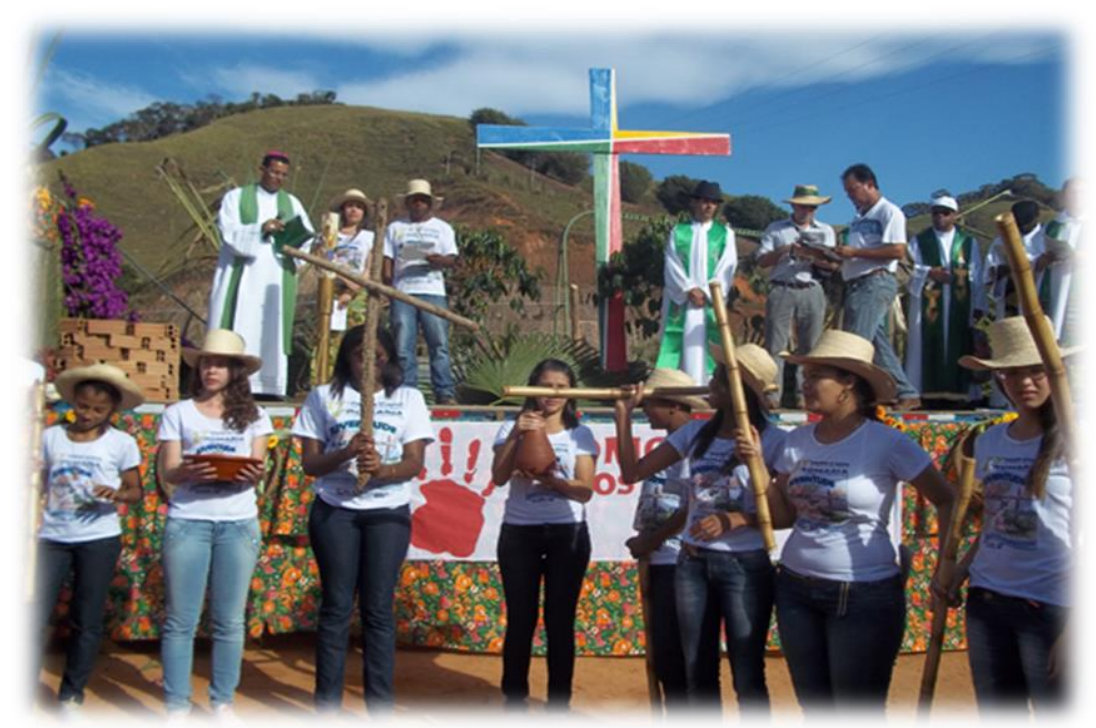

Figura 3 - Romaria dos Trabalhadores, mística com jovens agricultores Fonte: Tribuna de Muriaé, 2013.

Por fim, destacamos os processos de resistência inerentes a informação/educação. Este tipo de ação não tem por intenção a reunião de pessoas 'físicas' e de forma presencial, mas comumente pretender mudar opiniões de massa através da mídia e de oportunidades de educação, ou seja, tende a levar um tipo de "ideia" - que é expressão de um coletivo ou de uma instituição - para o maior número de pessoas fazendo com que estas possam compartilhar e compactuar informações comuns. Os veículos de disseminação são os mais diversos, entretanto, nos últimos anos temos uma predominância da internet em conjunto com a mídia televisa. Ressalta-se que agricultores familiares, ainda mais na década de 90 , não possuíam domínio sobre estes tipos de mídias, sendo que as notícias vinculadas, feitas com ajuda de outros atores sociais, se davam em informativos e jornais locais. Os movimentos eclesiais auxiliam de forma particular nesse tipo de estratégia, tendo em vista que usar o nome da Igreja ou a figura de um Padre ressalta emoções e atribuem valores simbólicos à informação. Para os casos que retratam as mobilizações coletivas envolvendo a Arquidiocese de Mariana, destacamos as diversas entrevistas e depoimentos de sacerdotes e líderes das Comunidades Eclesiais de Base. E, de forma bastante peculiar, as mudanças de conteúdo do jornal oficial da Arquidiocese.

No trabalho de Oliveira, Pagnossa e Zangelmi (2011) foram abordados diversas mudanças de conteúdo que aconteceram no jornal da Arquidiocese. Essas mudanças foram fruto, dentre outros motivos menores, da troca ocorrida na alta hierarquia da Igreja Católica e isso influenciou na frequência e no conteúdo das mensagens direcionadas aos agricultores vítimas dos conflitos com grandes empreendedores na região. As mudanças seguiram os episódios já abordados em tópicos anteriores sobre a Estrutura de Oportunidade Política que se formou no final da década de 80. Assim, o "Arquidiocesano", nome do jornal na época de Dom Oscar, não tinha em suas páginas matérias que permitiam a evidenciação de grupos progressistas que surgiam após a redemocratização do país. Em outras palavras, o periódico tinha como objetivo difundir assuntos religiosos, não políticos, a priori. Posteriormente, com a nomeação de Dom Luciano o informativo passou a se chamar "O pastoral" e seu conteúdo se voltou para questões relacionadas ao combate das desigualdades sociais e incentivo de lutas populares coletivas, como podem ser vistas nos trechos abaixo. 
O XII Encontro das Comunidades Eclesiais de Base da Arquidiocese de Mariana desponta como um grande marco da caminhada eclesial de nossa Arquidiocese. Lembro-me que os encontros anteriores aconteciam anualmente. Quem ficava sabendo? Como eram preparados? Quem participava? Sem dúvida que havia os responsáveis por eles. Tenho certeza que eram preparados com carinho e esmero. Mas, por uma serie de fatores, atingia uma parte muito pequena da Arquidiocese. Mesmo por que a Arquidiocese como um todo não havia feito sua opção pelas CEBs. Nem por isso deixaram de cumprir seu papel. Aliás, há que se ressaltar que, se chegamos ao XII Encontro, é graças à resistência daqueles que acreditaram nas CEBs como uma realidade possível também para a arquidiocese de Mariana [...]

O chavão que "as CEBs são grupos políticos" já se tornou anacrônico. A desculpa é que a diocese de que Mariana tem muitos padres e por isso os leigos não precisam assumir ministérios se contradiz com o acúmulo de trabalho da parte de muitos párocos. O "Rosto da Igreja" que este encontro deverá nos fazer encontrar é o rosto do próprio Cristo identificado com os pobres e excluídos. A partir daí é só organizar as comunidades para ser seu espaço de luta, de reivindicação, de celebração da própria fé. É só deixar que com elas nasçam as CEBs, o novo jeito da Igreja ser (Jornal "O Pastoral", ano IV, Mariana, Julho de 1994 apud OLIVEIRA, PAGNOSSA e ZANGELMI, 2011, p.549).

As formas de resistências apresentadas ao longo deste tópico são apenas alguns exemplos das infinitas possibilidades que os grupos em prol da defesa de seus direitos se apropriam. Entretanto, cumpriu o objetivo do trabalho que foi mostrar que o apoio de representantes de grupos eclesiais junto aos movimentos sociais e aos agricultores se tornaram importantes, quando não, essenciais para a conquista de algumas demandas.

\section{CONCLUSÃO}

Para os casos de Ação Coletiva apontadas neste trabalho a fé, aliada a um quadro de injustiça social, são elementos importantíssimos para a reunião de sujeitos que de outra forma pouco provavelmente se juntariam em episódios de mobilização social. Nesse sentido a Igreja Católica tem muito a oferecer aos movimentos sociais. Constitui-se numa instituição, que dentro de uma rede de resistência, se sobressai no que tange ao carisma empregado, ao longo da história, que independente da religião, se acredita em Deus ou não, imprime considerável respeito, inclusive sobre o Estado, estimado laico. Pode-se afirmar dessa forma, que de um modo geral, nos conflitos onde a Igreja atua em favor das comunidades atingidas percebe-se vantagens em comparação a outras que não possuem o apoio desta instituição.

Parece-nos, ademais, que a atuação da Igreja Católica no meio rural e a simpatia ou adequação aos princípios da Teologia da Libertação são sinônimos. Esta Teologia por muitas vezes está no centro das discussões. Dentro da Igreja soa como motivo de dicotomias e desavenças entre sacerdotes e para as comunidades como motivo de união. É claro que para as comunidades organizadas saber se tal Teologia está em consonância com os ideais Marxistas não faz o menor sentido. Em verdade, influenciados por líderes religiosos e comunitários, provavelmente raramente escutaram esses termos. Mas, para a Igreja ser ou não adepto da Teologia da Libertação faz uma enorme diferença, tendo em vista todo o histórico de embates entre setores progressistas e conservadores. Assim, a mudança de um bispo conservador para 
outro alinhado com as propostas progressistas influenciou em muito no surgimento de movimentos de base na região da Zona da Mata Mineira.

Ressaltamos que a ousadia de enquadrar os tipos de Ação Coletiva em categorias de estudo nomeadas aqui como técnico-científico, enfrentamento direto e educação-informação, foi um esforço analítico com o objetivo de evidenciar características comuns destes tipos de movimentos sociais. Concomitante, a complexidade dos processos de resistência nesse território, a sua extensão e a falta de um recorte temporal preciso foram limitadores deste trabalho, que pretendeu apenas uma generalização a partir da teoria e dos dados coletados. É preciso colocar na agenda de pesquisas futuras estudos de casos locais - de caráter micro-sociológico, sobretudo - ao passo que podem dar indícios da efetividade de determinadas teorias mais abrangentes. Suscita, portanto, o mergulho em estudos futuros e profundos sobre as estratégias utilizadas pelas comunidades rurais em contextos de conflitos, com uma delimitação territorial e temporal menos abrangente, tendo em vista a Zona da Mata Mineira.

Cabe evidenciar, por fim, que ao mesmo tempo em que os movimentos de resistência lançam mão de estratégias antigas como as invasões, os acampamentos e as passeatas, trazem elementos novos como o uso das redes sociais, por exemplo. A Igreja é, portanto, um diferenciador, que adiciona elementos místicos ao contexto, funcionando como um 'tempero' nas lutas sociais existentes.

\section{REFERÊNCIAS BIBLIOGRÁFICAS}

1. ACSELRAD, Henri. Ambientalização das lutas sociais - o caso do movimento por justiça ambiental. Estudos avançados, v.24, n.68, 2010.

2. ALEXANDER, Jeffrey Charles. Ação coletiva, cultura e sociedade civil: Secularização, atualização, inversão, revisão e deslocamento do modelo clássico dos movimentos sociais. Revista Brasileira de Ciências Sociais, v. 13 n. 37, São Paulo, 1998.

3. ALONSO, Angela. As teorias dos movimentos sociais: um balanço do debate. Lua Nova, São Paulo, n.76, 2009.

4. CARVALHO, Virgínia Donizete de; BORGES, Livia de Oliveira; Denise Pereira do Rêgo. Interacionismo Simbólico: Origens, Pressupostos e Contribuições aos Estudos em Psicologia Social. Psicologia Ciência e Profissão, v.30, n.1, 2010.

5. FONSECA, Bruno Costa da; OLIVEIRA, Marcelo Leles Romarco de; SOUSA, Dayane Rouse Neves. Análise dos potencializadores de conflitos socioambientais inerentes ao uso e apropriação de recursos na bacia do Rio Doce. In: V Simpósio Internacional de Geografia Agrária - VI Simpósio Nacional de Geografia Agrária, Belém. Anais... Belém: 2011.

6. FONSECA, Bruno Costa da; OLIVEIRA, Marcelo Leles Romarco de; SOUSA, Dayane Rouse Neves. Conflitos ambientais: atores, causas e desdobramentos na Zona da Mata Mineira. Caminhos de Geografia Uberlândia, v.13, n.42, 2012.

7. GIL, Antonio Carlos. Como Elaborar Projetos de Pesquisa. 4ạ ed. São Paulo: Atlas, 2002.

8. GOHN, Maria da Glória. Teoria dos Movimentos Sociais: Paradigmas clássicos e contemporâneos. São Paulo: Loyola, 1997.

9. GOSS, Karine Pereira; PRUDENCIO, Kelly. O conceito de movimentos sociais revisitado. Revista Eletrônica dos Pós-Graduandos em Sociologia Política da UFSC, v.2, n.1, 2004. 
10. IOKOI, Zilda Grícole. Igreja e camponeses: Teologia da Libertação e Movimentos Sociais no Campo Brasil e Peru, 1964-1986. São Paulo: Editora Hucitec, 1996.

11. JÚNIOR, João Alfredo Costa de Campos Melo. A ação coletiva e seus intérpretes. Pensamento Plural, v.1, 2007.

12. KLEIN, Estanislau Paulo. O Aprendizado de Lideranças no Contexto de Comunidades do Acre onde Houve uma Sintonia com a Teologia da Libertação. In: BROSE, Markus (org). Lideranças para a democracia participativa: Experiências a partir da Teologia da Libertação, Goiânia: Editora da UCG, 2009.

13. LEVY, Charmain. Influência e contribuição: a igreja católica progressista brasileira e o fórum social mundial. Religião e sociedade, v.29 n.2, Rio de Janeiro, 2009.

14. LÖWY, Michel. O catolicismo latino-americano radicalizado. Tradução: Mário Laranjeira. Estudos avançados, v.3 n.5, São Paulo, 1989.

15. MCADAM, Doug; TARROW, Sidney; TILLY, Charles. Para mapear o confronto político. Lua Nova, São Paulo, n.76, 2009.

16. MELUCCl, Alberto. Um objetivo para os movimentos sociais? Lua Nova, n.17, São Paulo, 1989.

17. MISOCZKY, Maria Ceci Araujo; FLORES, Rafael Kruter; SILVA, Sueli Maria Goulart. Estudos organizacionais e movimentos sociais: o que sabemos? Para onde vamos? Cadernos Ebape, v.6, n.3, 2008.

18. OLIVEIRA, Fabrício Roberto Costa, PAGNOSSA, Tadeu Pamplona, ZANGELMI, Arnaldo José. Os processos de transformações na Arquidiocese de Mariana: uma análise dos jornais "O Arquidiocesano" e "O Pastoral”. Revista de Humanidades, v.11, Rio Grande do Norte, 2011.

19. OLIVEIRA, Fabrício Roberto Costa. Religião e mobilização social na arquidiocese de Mariana/MG. 2005. 174f. Dissertação (Mestrado em Extensão Rural) - Departamento de Economia Rural, Universidade Federal de Viçosa, Viçosa. 2005.

20. OLIVEIRA, Fabrício Roberto Costa; ROTHMAN, Franklin Daniel. Arquidiocese de Mariana, Teologia da Libertação e Emergência do Movimento dos Atingidos por Barragens do Alto Rio Doce (MG). Política e Sociedade, Santa Catarina, n.12, 2008.

21. ROTHMAN, Franklin Daniel. A expansão dos projetos de barragens e mineração na Zona da Mata - MG: articulando as lutas de resistência a favor da agricultura familiar. In: Seminário Nacional sobre Desenvolvimento e Conflitos Ambientais, Universidade Federal de Minas Gerais, 2008.

22. SILVEIRA, Diego Omar da; OLIVEIRA, Fabrício Roberto Costa; FERREIRA, Rodrigo Souza. In nomine Jesu: Entrevista com Dom Luciano Mendes de Almeida. Revista eletrônica Cadernos de História, Ouro Preto, v.1, n.2, 2006.

23. TRIBUNA DE MURIAÉ. Romaria dos Trabalhadores. 2013. Disponível em http://tribunademuriae.com.br/site/2013/07/21/romaria-das-aguas-e-da-terra-aconteceuem-miradouro-e-foi-acompanhada-por-romeiros-de-todo-o-estado-de-minas-gerais/>. Acesso em 15 de janeiro de 2015.

24. ZHOURI, Adréia; ROTHMAN, Franklin Daniel. Assessoria aos atingidos por barragens em Minas Gerais: desafios, limites e potencial, in: Franklin Rothman (org.), Vidas alagadas: conflitos socioambientais, licenciamento e barragens, Viçosa: UFV, 2008. 